\title{
Abdominal pain and leg lesions: is there a connection?
}

\author{
Ankita Kapoor, ${ }^{1}$ Muhammad Hashim Hayat, ${ }^{2}$ Amman Yousaf $\quad$ (1) , ${ }^{3}$ Raseen Tariq ${ }^{4}$
}

${ }^{1}$ Internal Medicine, Rochester General Hospital, Rochester, New York, USA

${ }^{2}$ Department of Medicine Division of Gastroenterology, Hepatology and Nutrition, Vanderbilt University Medical Center, Nashville, Tennessee, USA

${ }^{3}$ Radiology, Hamad Medical Corporation, Doha, Ad Dawhah, Qatar

${ }^{4}$ Gastroenterology and Hepatology, Mayo Clinic Minnesota, Rochester, Minnesota, USA

Correspondence to Dr Amman Yousaf: drammanyousaf@yahoo.com

Accepted 21 March 2021

\section{DESCRIPTION}

A 63-year-old woman presented to the outpatient primary clinic with tender erythematous nodules and ulcers draining oily brown material on bilateral lower extremities (figure 1A). Her medical history was notable for an episode of pancreatitis and pancreatic pseudocyst, 4 years ago. The lesions appeared a week ago and progressed from areas of erythematous macules (figure $1 \mathrm{~B}$ ) to tender nodules and few evolved into ulcers draining an oily brown material (figure 1A). At the time of presentation, she also had nausea and mild abdominal pain. Physical examination was remarkable for skin changes and mild abdominal tenderness. On laboratory investigations, serum amylase and lipase levels were 3804 and $5775 \mathrm{U} / \mathrm{L}$, respectively. CT scan showed enlarged pancreatic duct measuring $7 \mathrm{~mm}$ with unchanged cystic mass up to $1.6 \mathrm{~cm}$ in the uncinate process with mild pancreatic inflammation. She was admitted to the hospital for management of acute pancreatitis with intravenous fluids and pain medications. Biopsy of the skin lesions revealed lobular panniculitis without vasculitis, necrosis of adipocytes with formation of 'ghost adipocytes' (enucleated cells after coagulation necrosis) and calcium deposition, pathognomonic for pancreatic panniculitis (figure 2). She was discharged from hospital, her lesions completely resolved on follow-up visit 4 weeks later and is currently scheduled for outpatient endoscopic ultrasound to rule out underlying pancreatic malignancy.

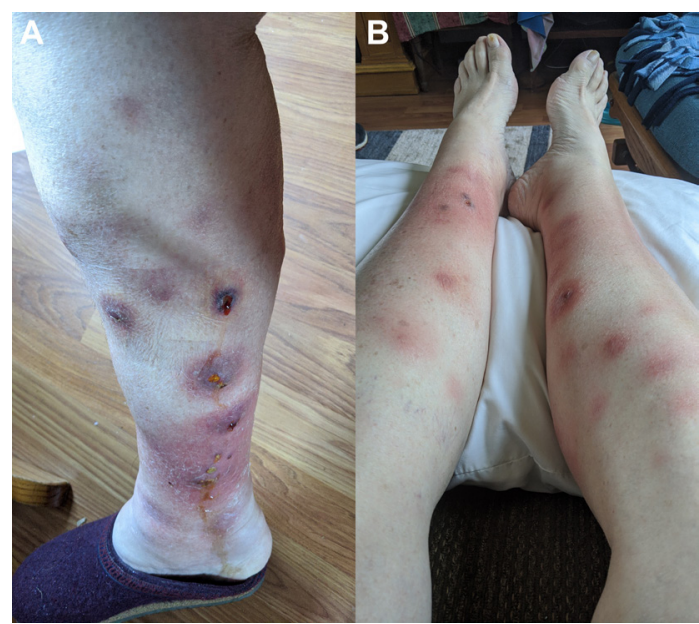

Figure 1 (A) Anterior view of bilateral lower extremities showing lesions evolved into ulcers with drainage (at presentation). (B) Anterior and lateral view of right lower extremity showing tender erythematous nodules (1 week prior to presentation).

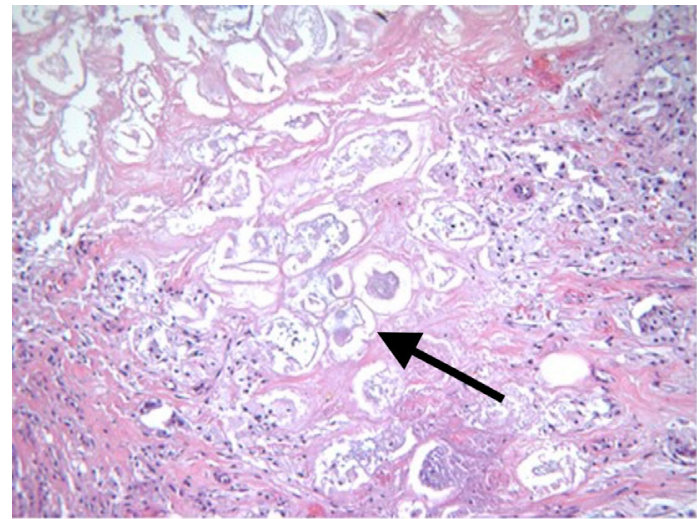

Figure 2 Biopsy of the skin lesions showing lobular panniculitis without vasculitis; necrosis of adipocytes with formation of 'ghost adipocytes' (enucleated cells after coagulation necrosis) and calcium deposition, pathognomonic for pancreatic panniculitis (black arrow).

Pancreatic panniculitis is a rare cutaneous manifestation which is observed in 2\%-3\% of individuals with pancreatic disease. ${ }^{1}$ The lesions are usually due to subcutaneous fat necrosis mainly of the extremities and present as inflammatory nodules and plaques which may ulcerate and exudate. ${ }^{1}$ It is mostly associated with acute or chronic pancreatitis but can harbinger pancreatic carcinoma (most frequently acinar type) and can precede neoplasia by several months. ${ }^{2}{ }^{3}$ Recurrent or persistent pancreatic panniculitis warrants screening for occult pancreatic malignancy. ${ }^{2}$ Skin lesions improve with managing the underlying condition. ${ }^{4}$ Symptomatic relief can be achieved by non-steroidal anti-inflammatory drugs. ${ }^{4}$

\section{Learning points}

- Pancreatic panniculitis is a rare cutaneous manifestation which is observed in $2 \%-3 \%$ of individuals with pancreatic disease; hence, patients presenting with skin lesions and abdominal pain should be promptly evaluated for a possible diagnosis of pancreatitis to avoid delay in management.

- It is mostly associated with acute or chronic pancreatitis but can harbinger pancreatic carcinoma (most frequently acinar type) and can precede neoplasia by several months.

- Patients with recurrent or persistent pancreatic panniculitis should be screened for occult pancreatic malignancy. 
Some studies suggest benefit from octreotide, a synthetic somatostatin-like polypeptide, which inhibits pancreatic enzyme production. ${ }^{5}$

Contributors AK: Drafted and revised the manuscript. MHH: Drafted and revised the manuscript. AY: Drafted and critically revised the manuscript. RT: Drafted, revised the manuscript and gave the final approval for submission.

Funding The authors have not declared a specific grant for this research from any funding agency in the public, commercial or not-for-profit sectors.

Competing interests None declared.

Patient consent for publication Obtained.

Provenance and peer review Not commissioned; externally peer reviewed.
ORCID iD

Amman Yousaf http://orcid.org/0000-0003-0646-508X

\section{REFERENCES}

1 Requena L, Sánchez Yus E. Panniculitis. Part II. mostly lobular panniculitis. J Am Acad Dermatol 2001;45:325-64.

2 Zundler S, Strobel D, Manger B, et al. Pancreatic panniculitis and polyarthritis. Curr Rheumatol Rep 2017:19:62.

3 Zhang G, Cao Z, Yang G, et al. Pancreatic panniculitis associated with pancreatic carcinoma: a case report. Medicine 2016;95:e4374.

4 Torres-Navarro I, Rojas-Ferrer N, Botella-Estrada R. Pancreatic panniculitis. Rev Esp Enferm Dig 2019;111:812-3.

5 Hudson-Peacock MJ, Regnard CF, Farr PM. Liquefying panniculitis associated with acinous carcinoma of the pancreas responding to octreotide. J $R$ Soc Med 1994:87:361-2

Copyright 2021 BMJ Publishing Group. All rights reserved. For permission to reuse any of this content visit https://www.bmj.com/company/products-services/rights-and-licensing/permissions/

BMJ Case Report Fellows may re-use this article for personal use and teaching without any further permission.

Become a Fellow of BMJ Case Reports today and you can:

- Submit as many cases as you like

- Enjoy fast sympathetic peer review and rapid publication of accepted articles

- Access all the published articles

Re-use any of the published material for personal use and teaching without further permission

Customer Service

If you have any further queries about your subscription, please contact our customer services team on +44 (0) 2071111105 or via email at support@bmj.com.

Visit casereports.bmj.com for more articles like this and to become a Fellow 